\title{
Female as an icon of exquisiteness in Pakistani Art
}

\author{
Farah Khan $^{*}$ \\ Department of Visual Arts, Institute of Visual Arts \& Design, Lahore College for Women University, Lahore, Pakistan
}

Received 20 Sept 2018, Accepted 25 Nov 2018, Available online 27 Nov 2018, Vol.6 (Nov/Dec 2018 issue)

\begin{abstract}
The image of female in art has remained a subject of interest since prehistoric age. Representation of female has left strong mark on the aesthetic sensibility of artists globally. Looking at the history of Pakistani Art, it is observed that the exquisiteness of female as an icon has influenced the creative practice of the local artists. Female as an image is represented by many artists with diversity of subject matter, medium and technique. This subject of artistic expression has left unique impact in the development of art which can easily be analyzed looking at the present account of Pakistani art.
\end{abstract}

Keywords: Pakistani art, artists, creative practice, female as an icon of exquisiteness, artistic expression, prehistoric age.

\section{Introduction}

Pakistan is a country which shares evidences of art that dates back to the prehistoric time period and is associated with one of the ancient civilizations of the world i.e., Indus Valley Civilization. Art of Pakistan is rich in terms of subject matter and artistic expression. Though, there is no specific school of thought in general but artists from all over the region are working under diversified school of thoughts whether based on the philosophies of indigenous references or inspired by the notions of western art. Female as an icon of exquisiteness has been depicted in Pakistani art as a key feature with aesthetic interpretation.

It has been observed that female figure has always been given immense importance in art throughout the ages. A female is supposed to be the perfect unit of divine beauty and power. The portrayal of female beauty in art has a long historical background. From Paleolithic age to date female imagery has been used with diversified philosophies. Different cultures and religions have diversified means of expression while interpreting female imagery in art.

Before analyzing the iconic references of female imagery in Pakistani art, it is integral to look into the history of this region. Besides this, the overview of this subject of interest in other cultures is also required. Pakistan shares a long history with India before partition and both shares similarities in culture, traditions and in

*Corresponding author's ORCID ID: 0000-0002-1034-5374 DOI: https://doi.org/10.14741/ijmcr/v.6.6.12 art as well. Depiction of a female figure was the utmost desire of many artists. In Indian art female is strongly associated with its religion where art, man and religion all became one and serves as representative of their psychological conceptions. Indian art greatly deals with the philosophy in which man and nature became integral parts, where nature symbolizes the women. Feminine exquisiteness is observed to be the main theme of Indian art and is sometimes called to be the female art. A female who is rendered as a goddess also represents the feminine aspect of the divine and the erudition that is associated with divine power. The Goddess is considered to be the divine energy in motion. She is associated with the aspects of power such as a life-giving mother, a strong counterpart of the male being a representative of his strength/shakti. Though in Pakistani art, human imagery is not associated with religious aspect but a number of artists have used female figure as a unit of perfection and some have used it for the sake of pleasure while others for depicting social issues and the list goes on.

All over the world, the depiction of female varies in its context. It has always believed that everything in this world has a deeper philosophy; there is always a reason behind the birth of everything, every concept and image. No doubt, that God is the greatest creator of beauty that lies in its perfection. He has created everything having a significant meaning or ideology, nothing that exists is meaningless. He has created women, so there must be a strong reason behind her birth. She has been created for man as his power and counterpart; she also served as a source of inspiration and creation. She is on one side a loving, caring companion of the man who can brought positive changes in his life and on the other side she has 
the power to destroy also. She is blessed with inner strength along with external beauty; her inner strength is in fact her real grace.

For the comprehension of this focus of study, it is integral to have a comparative analysis of female imagery used in different regions. As it has been mentioned earlier that women are considered as the divine beings associated with religious beliefs in Indian art. The portrayal of this imagery in art shares a long historical background, the noticeable quality of which lays in its rendering and concept that varies with the passage of time. The representation of female imagery originated in art from Paleolithic small figurines of mother goddesses. These sculptures served as symbols of fertility, they were used in religious ceremonies having magical significance as well, which ensured the safe and sound birth of the child. One such example is the Venus of Lespugue made of fine ivory carving, this miniature sculpture of six inches, dates back to Paleolithic age (c. 23,000 BC) which is among the collections of Musee de l'Homme in Paris, France (fig. 1). This sculpture served as the symbolical representation of fertility, she is the mother Goddess. ${ }^{2}$ This shows that the people of Paleolithic age were also aware of the importance of females. They were suffering from the tragedy of survival; they wanted to increase their number and for that specific reason, they used these fertility symbols. This sculpture explains all the characteristics of the female goddess; the artist has exaggerated the body parts of the female, executed with broad hips and heavy breast. Her realistic characterization is missing here, she is composed of ball like shapes because she is not representing a specific one but is representative of the female gender.

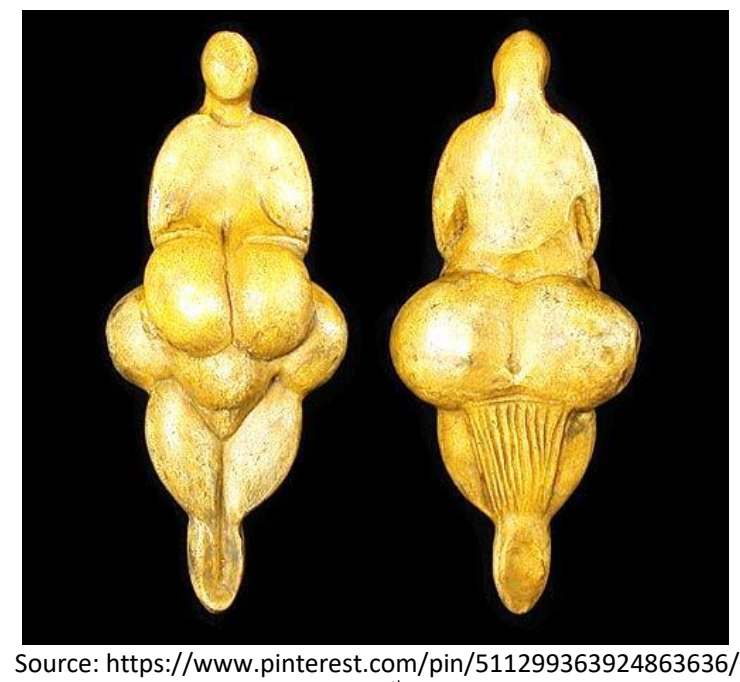
(accessed on $12^{\text {th }}$ June, 2018)

Figure. 1. Venus of Lespugue, ivory, $6^{\prime \prime}$, collection of Musee de I'Homme in Paris, France. (c. 23,000 BC).

A goddess is a female associated with divine power and beauty, a super natural being worshipped by people. It is

\footnotetext{
2. Fred S.Kleiner, Christin J. Mamiya. Gardener's Art through the Ages. 12th Ed (New York: Thomson Wordsworth, 2005), 18.
}

not surprising that she is blessed with the power of procreation being an important part of the nature associated with creative forces in the universe. God is the creator of life and she is the source of creation on earth. Throughout history, in Middle East and Mediterranean, she has been represented having significant character with different names: Ishtar in Babylonia, Astarte in Syria, Isis in Egypt and Aphrodite in Greece. ${ }^{3}$ The scholars considered all of them as manifestation of a single powerful concept that is the Great Mother Goddess who is the mother of earth; she symbolizes life forces and nature, besides this she also controlled nature, season and fertility of the plants, animals as well as humans. ${ }^{4}$ She is considered to be the divine energy in motion. In the history of art, another term used for the Goddess is Venus, which was given by the Romans. This term is frequently used in Europe. The portrayal of Goddess was under practice in almost all the early civilizations of the world but with a significant change in character according to the varied philosophies, culture, and religious beliefs.

In South Asian Art, image of a female also acquires great importance. The evidences of the concept of female's exquisiteness are present in the terra cotta figurines found from the Indus Valley Civilization dated back to ca. 2300- 1750 BC (fig. 2). These are not images, these are symbols. They do not pretend to represent the physical impression of the female form. These terra cottas include great numbers of mother goddesses, not too different found from the other early cultures. ${ }^{5}$

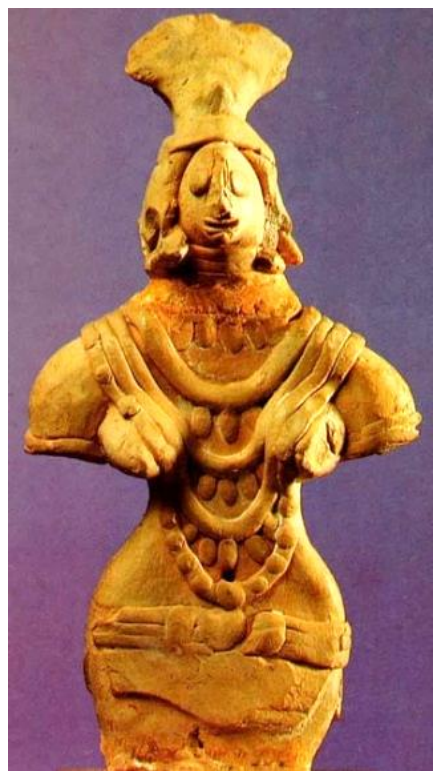

Source: https://historum.com/threads/possible-cult-from-ivc-and-itscontinuation-into-the-historical-periods.58637/ (accessed on $3^{\text {rd }}$ June, 2018)

Figure. 2. Mother Goddess from Indus Valley Civilization, terra cotta (c. 2600-1900 BC).

\footnotetext{
${ }^{3}$. Fred S. Kleiner, Christin J. Mamiya. Gardener's Art through the Ages. 12th Ed (New York: Thomson Wordsworth, 2005), 167.

4 . Ibid.

5. Roy C. Craven. Indian Art: A Concise History. (London: Thames and Hudson, 1976), 19.
} 
Another important example found from Indus Valley Civilization is the figurine of a dancing girl made in bronze ca. 2300-1750 BC (fig. 3). ${ }^{6}$ She is standing nude except for a brief necklace and an arm completely ringed with bangles, her relaxed body twists so that one hand rests on her right hip while the other rests on her left leg. This is the most impressive of Indus figurines; she is considered to be the prototype of Indian Shalabhanjika which is evident through the portrayal of her pose.

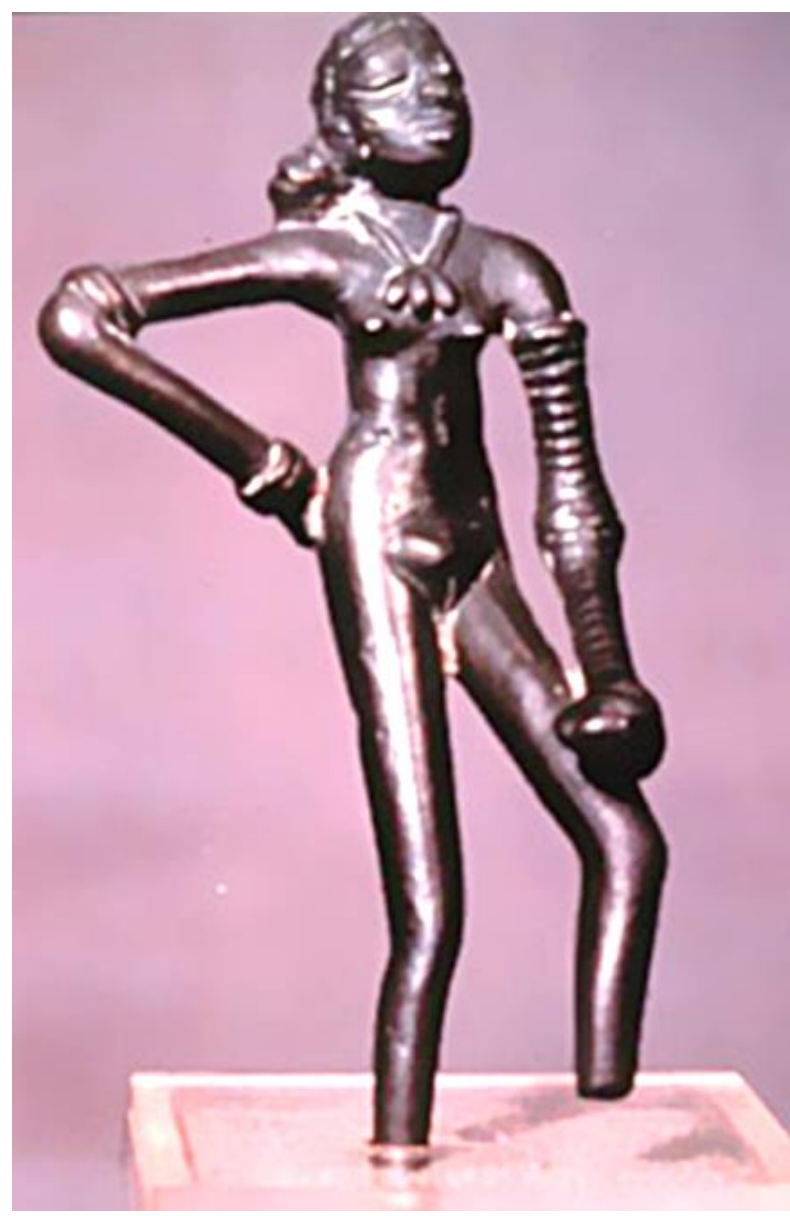

Source: https://prajakta2818.wordpress.com/2016/11/23/dancing-girlof-mohenjodaro-indus-valley-civilization/ (accessed on $15^{\text {th }}$ June, 2018)

Figure. 3. Dancing Girl from Mohenjo-daro, bronze (c. 2500 BC).

The most notable figure that has been used in Indian art is the figure of a yakshi who is supposed to be the semidivine being (fig. 4). ${ }^{7}$ She has been portrayed with the celestial beauty, having feminine sensuousness and divine quality. In Indian art, there was no disinclination in the execution of these nude feminine divine beings. Nudity was not considered a sin but it was taken as a symbol for revealing the pure and natural essence of divine beauty hidden behind the physical appearance.

\footnotetext{
6. Mortimer Wheeler. Civilization of the Indus Valley and beyond. (London: Thames and Hudson, 1967), 44.

${ }^{7}$. Roy C. Craven. Indian Art: A Concise History. (London: Thames and Hudson, 1976), 19.
}

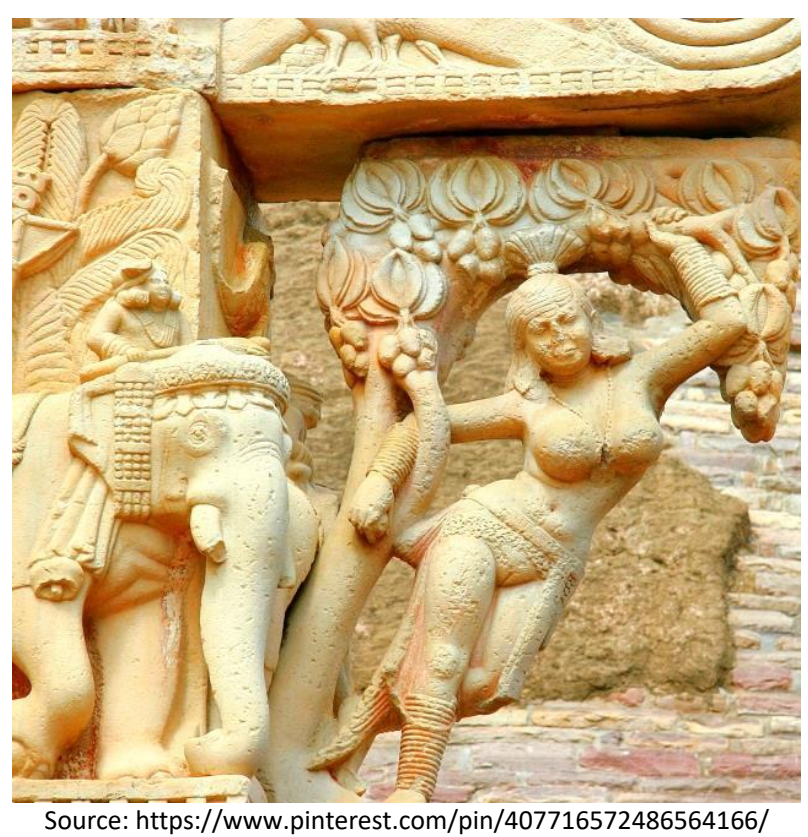

(accessed on $15^{\text {th }}$ July, 2018)

Figure. 4. Yakshi bracket figure on the eastern gate of Bharhut Stupa, India (c. 125-100 BC).

The depiction of female in Western Art is different as compared to the Indian art, besides the figure of Marry, sensuousness prevails in almost all art forms whether painting or sculpture etc. Birth of Venus (fig. 5) by Santro Botticelli (1445-1510) proves to be a landmark of early Renaissance, Italy. The concept of idealized beauty was eminent in this work. The ideal rendering of female figure who is the focal point of the composition, is observed to be an influential reference in the making of art both in the western and the eastern world. Though every artist adds a new dimension into it but it remained an everending subject of interest for the artists till to date.

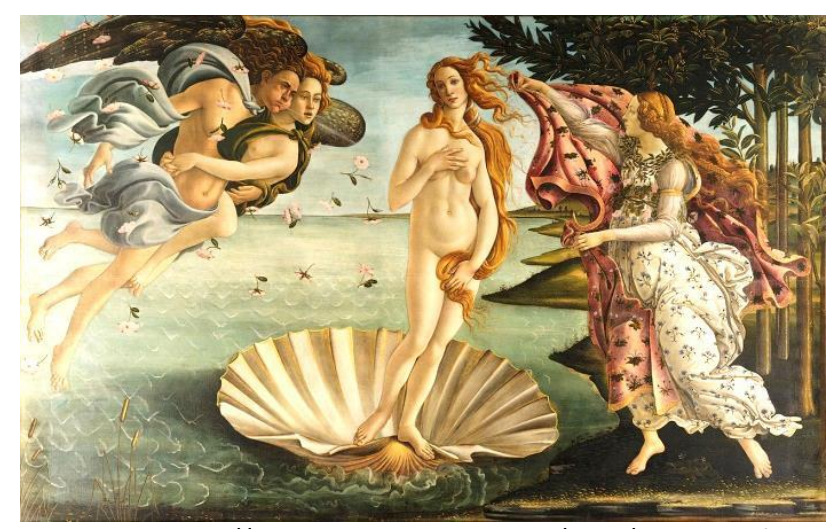

Source: https://artsandculture.google.com/asset/the-birth-ofvenus/MQEeq50LABEBVg?hl=en (accessed on $24^{\text {th }}$ October, 2018)

Figure. 5. Sandro Botticelli, The Birth of Venus, 1486 A.D, Tempera on panel, $172 \mathrm{~cm}$ x $278 \mathrm{~cm}$, Uffizi Gallery Italy.

Jean Auguste Dominique Ingres (1780-1867), a romantic painter is also known for making nude females surrounded by exotic elements (fig. 6). The photo-realistic quality of his work earned him a special place in the 
history of art. The sensuous yet imaginative quality kept in exotic surroundings were an exceptional feature in his paintings. The idealized female figure with elongated body and emphasis on the concept of beautification stands out to be a captivating feature in his work. His interest in beautifying his surfaces with embellishments of different kind also makes his work unique among his other contemporaries. Though he was inspired by the Madonna's of Raphael but establish her own distinguished style. His paintings had the sense of touch with the addition of three-dimensional quality.

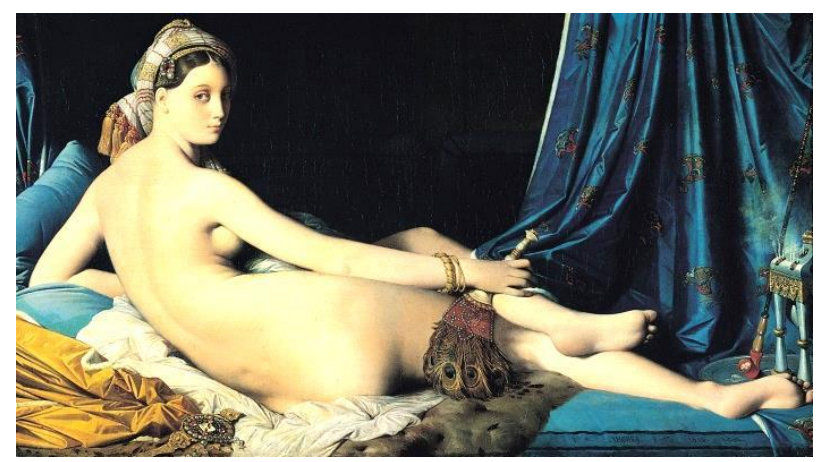

Source: https://smarthistory.org/between-neclassicism-andromanticism-ingres-la-grande-odalisque-2/ (accessed on $11^{\text {th }}$, June, 2018)

Figure. 6. Jean August Dominique Ingres, Grande Odalique. 1814 A.D, oil on canvas, $88.9 \mathrm{~cm} \times 162.56 \mathrm{~cm}$, Louvre Paris.

Moving from Ingres to Eugene Delacroix (1798-1863), from sensuous to thought-provoking depiction of female as the revolutionary image in his celebrated painting entitled Liberty leading the people by Delacroix changed the perception of people and made them realize that she is strong enough to lead a group of people rather than being a perfect model of beauty (fig.7).

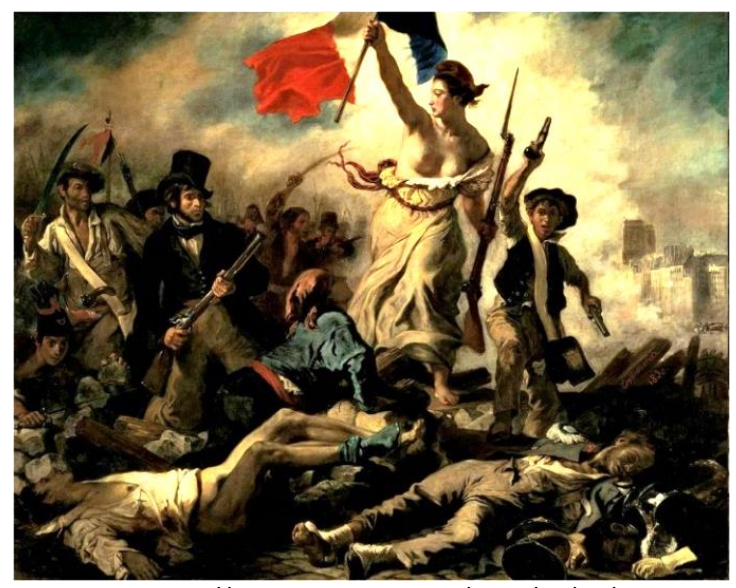

Source: https://deplatayexacto.com/2012/02/03/la-libertad guiando-al-pueblo-eugene-delacroix-1830/ (accessed on $8^{\text {th }}$ July, 2018)

Figure. 7. Eugene Delacroix, Liberty Leading the People, 1830, oil on canvas, $2.6 \mathrm{~cm} \times 3.25 \mathrm{~cm}$, Louvre Museum.

Liberty is shown as a leader of a group symbolizing freedom. This was the first ever image of western history, in which female was used as a sign of strength, motivation, uprising and success. No doubt, female is an integral feature of a society who owns a lot of responsibilities. She is a mother, a sister, a daughter, and a wife. Besides this she is the source of creation as well. This image records the modern approach of nineteenth century after the age of enlightenment when female was also considered to be a role model. She is shown here as a revolutionary figure who is holding a tri-color flag representing, peace, freedom, love and passion for its nation and people. She is portrayed as a sign of uprising.

Females have also been depicted while working in fields as observed in the realistic paintings of Jean Francois Millet (1814-1875). He portrayed them as an integral part of the society (fig. 8). The females painted by Millet are shown as a sign of strength. These females in their figural representation resemble the masculine structure. They are shown as the heroic symbol of working class. Though Millet did not focus on their faces and gestures but highlighted their activity which is a hard task to achieve for a female who is considered to be the sensitive creation of God (physically and emotionally) but here he accentuated that she owns in herself the strength for making everything possible. Her beauty lies in her strength and her attitude towards reality.

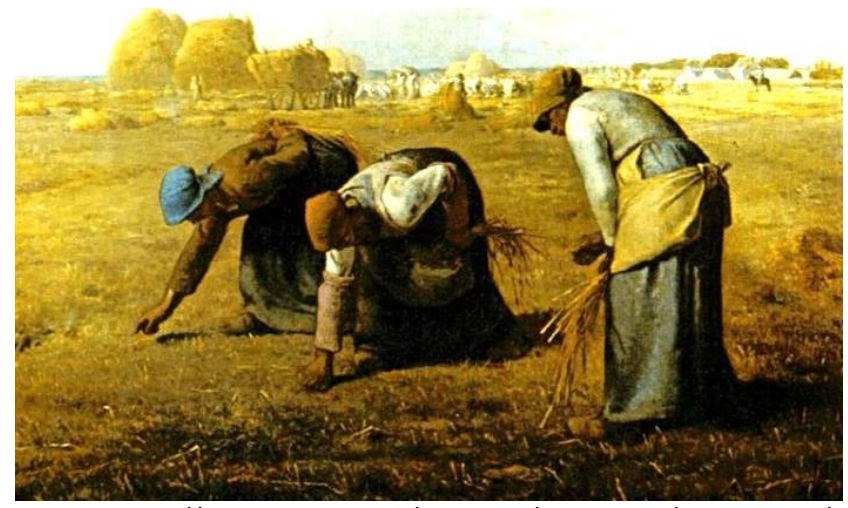

Source: https://www.theartist.me/collection/oil-painting/the-gleaners/ (accessed on $5^{\text {th }}$ August, 2018)

Figure. 8. Jean Francois Millet, The Gleaners, 1857, oil on canvas, $83.8 \mathrm{~cm} \times 111.8 \mathrm{~cm}$, Musee d' Orsay, Paris.

A complete movement based on feminism affected art forms starting from late $19^{\text {th }}$ century, and has left its profound effect on the works of different artists including Pakistani artists as well. In this context, it is appropriate to say that throughout history female imagery has been portrayed with diversified means of expressions.

Focusing on Pakistani art after independence, it is observed that a number of artists were working under different genres. For our convenience we can divide their work in groups. After partition artists were not working under any specific philosophy but with the passage of time, they developed within themselves a strong realization for conceptual work. The two prominent painters after independence, who were solely involved in the making of art were Ustad Allah Bux (1895-1978) and 
Abdur Rehman Chughtai (1894-1975). They contributed enormously in the production of art but they were following the same traditions which they were practicing even before partition. Both these renowned figures have experienced the incorporation of female imagery in their paintings with romantic expression. In the painting titled Sahelian (girlfriends) by Ustad Allah Bux, a group of females is shown surrounded with a romantic landscape that contains rustic feeling as well (fig. 9). The whole composition is flavored with the indigenous cultural essence. The details of dresses unfold the traditional sense of dressing with emphases on Punjabi culture. Females are also wearing jewelry that adds to the adornment of their characterization. Whereas, the style of Abdur Rehman Chughtai was distinct as compared to Ustad Allah Bux.

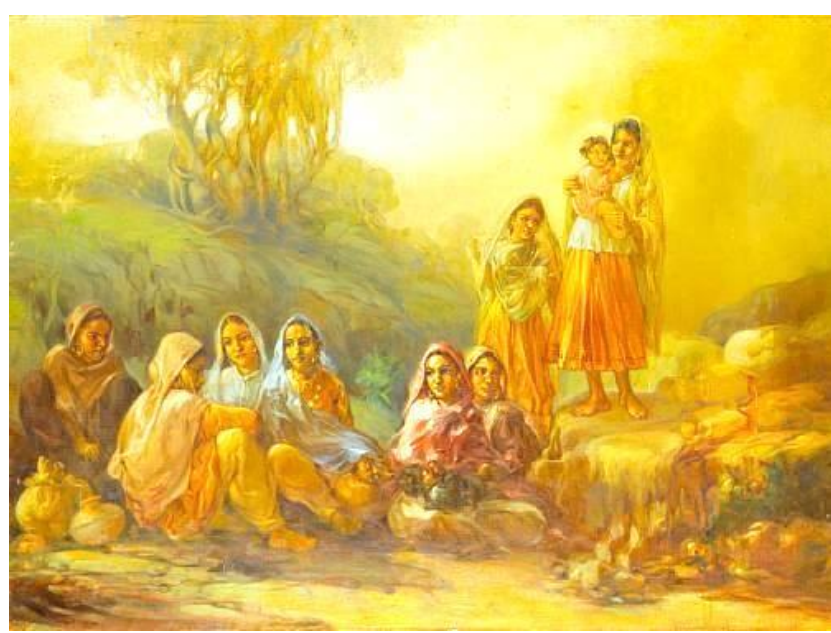

Source: https://www.mutualart.com/Artwork/Sahelian--Girl-Friends/0209B88412B1C62E (accessed on $1^{\text {st }}$, June, 2018)

Figure. 9. Ustad Allah Bux, Sahelian (girl friends), year unknown, oil on canvas $71.1 \times 96.5 \mathrm{~cm}$.

Abdur Rehman Chughtai used to create idealized figures mostly based on illustrations. He was inclined towards poetry and his paintings also owns a sense of poetry in expression. In (fig. 10), a female figure is visible in the center of the composition, with a parrot sitting on her left shoulder. The female is shown lost in her thoughts, while holding an ornament in her right hand. Allah Bux mostly used wash technique of Bengal school in his paintings and that gave his work a transparent fine effect. Though he also had inclination towards the decorative elements (mostly used in miniature painting) and these are among the characteristic features of his work as well. The female with delicate features enhanced her exquisiteness and adds to the adoration of his subject. The banyan trees portrayed at the background, compliment the color scheme used in the depiction of female and the parrot sitting on her shoulder. The rest of the environment is soothing and calm in visual representation.

Looking at the history of Pakistani art, it is evident that a number of painters used female imagery in their work as a subject of interest. Shakir Ali and Zubeida Agha both are considered to be the pioneering figures of Modern Art in Pakistan. They were inspired by cubism and incorporate the abstract imagery of female in their work. Zubeida's artistic career was a compromise between freedom and the conventions of respectability. ${ }^{8}$

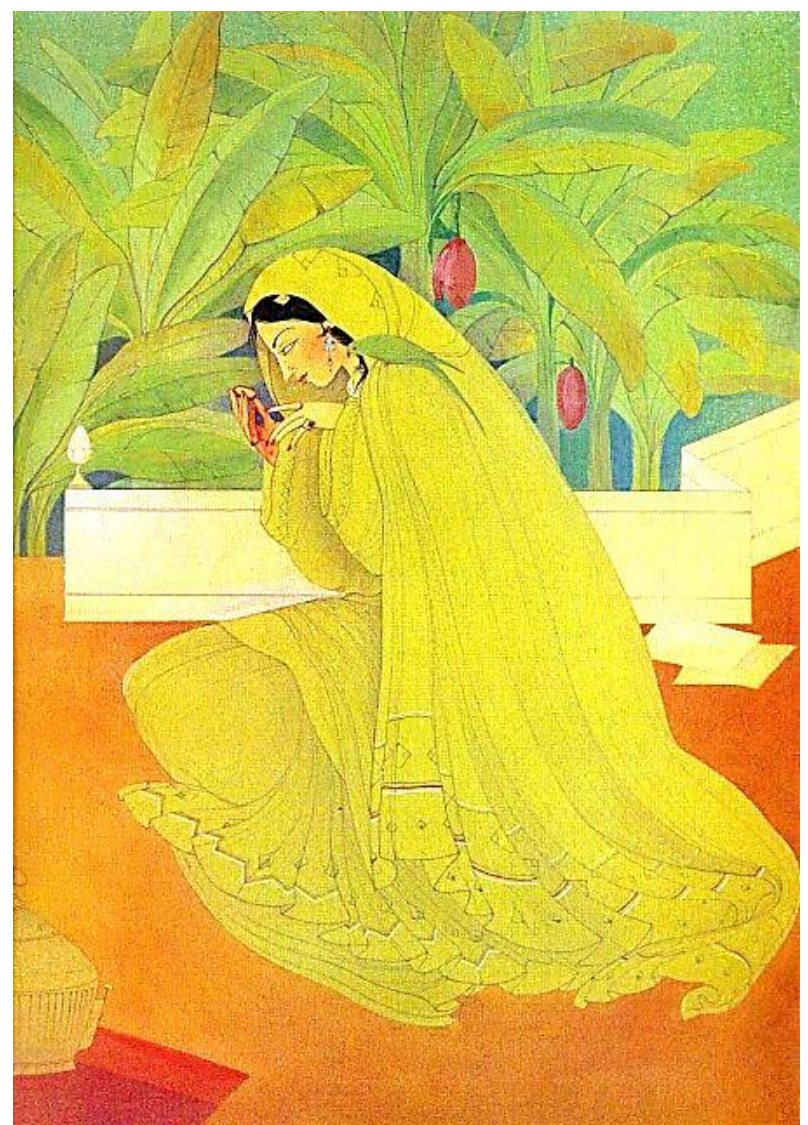

Source: https://www.amazon.in/Tallenge-Hiraman-Gallery-CanvasOffice/dp/B01N7TK1FL (accessed on $7^{\text {th }}$ July, 2018)

Figure. 10. Hiraman Tota by Abdur Rehman Chughtai, 1950, wash and tempera on paper, $44.5 \mathrm{~cm} \times 57.2 \mathrm{~cm}$, National Gallery of Modern Art New Delhi.

Naseem Hafeez Qazi (1928-1994), Salima Hashmi (b. 1942), Nahid Raza (b. 1947), Mehr Afroze (b. 1948), are among those female artists who also highlighted the female image with the infusion of conceptual approach in their work. Salima Hashmi was raised in a background that made her socially and politically conscious that is why her work contains a loud gesture of expressiveness with the flavor of conceptual approach as the main feature behind the visual imagery. Whereas, on the other hand Naseem Hafeez Qazi depicted females involved in daily life activities in their social setup. Besides these artists there is a list of painters who have painted female in their work.

Saeed Akhtar (b. 1938) is a master in this genre, the idealistic feminine gestures of the females make them celestial, to some extent it could be said that he is having

\footnotetext{
${ }^{8}$. Akbar Naqvi. Image and Identity: Fifty Years of Painting and Sculpture in Pakistan. (Karachi: Oxford University Press, 1998), 150.
} 
the same concept of beautification as we have seen in Indian Art. ${ }^{9}$ His ladies used to swing in celestial spaces, out of the realistic world, undraped yet draped with a transparent clothing and glorified by rich use of color palette (fig.11). Though, he is color blind but owned perfection in depicting rich colors. His main interest of painting remained the same till to date, feminine ideal grace and beauty was well preserved by him though he experiences some other subjects as well like calligraphy, sculpture and some other abstract figurative imagery. Saeed Akhtar deals with fantasized beauty which makes him ahead from his contemporaries. His command and control over this subject is unique in its expression. The idealization of Ingres was enhanced by Saeed Akhtar with the fusion of poetic gesture. His flexible female figures seem to move freely in the celestial environments as created by him. In this painting, a female figure is portrayed in a specific action with her face covered with hairs. Her sensuous body resembles with the idealized depiction of yakshi as visible in the Indian art. The bangles in her hands recollects the Rajasthani symbol of beautification. Her adornment with the addition of jewelry adds to her sensuous quality. Her arms are shown raised and the effect of her transparent, see-through layer of the frock gives an impression of flowing air whereas the overall image shows as if she is about to take a flight into her idealized world. At her back, reference of colorful wings is evident. They also add to the freedom of expression the artist enjoyed being involved in the creative process. This reference of wings is also noticeable in most of his paintings where they are associated with the iconic image of Buraq (a winged horse).

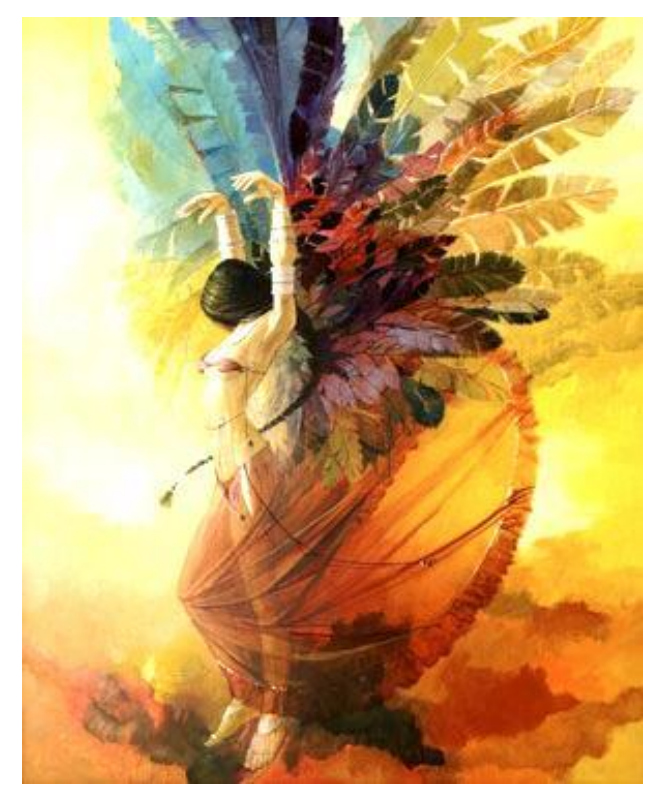

Source: http://www.fineartandyou.com/2013/08/pakistani-figurativeartist-saeed-akhtar.html (accessed on $17^{\text {th }}$ July, 2018)

Figure. 11. Saeed Akhtar, Untitled, 2009, oil on canvas, Private collection.

${ }^{9}$. Khalid Mehmood, interview by Farah Khan on $2^{\text {nd }}$ October, 2015.
Besides Saeed Akhtar, another master of this genre was Colin David. He is known for his unique compositions and fine brush work. Colin David (1937-2008) was one of those adroit artists who created human anatomy with the infusion of skill and imagination. The element of design in the form of figure always creates balance and harmony in his compositions as can be seen in (fig.12). Sense of space was an important subject in his paintings. David explored the female figure as a symbol of beauty and presented "women as women". He incorporated the image of women as an integral element in his work. He used to play with space on his surface and made it as an important element for designing his compositions. His approach was different from his contemporaries in terms of subjectivity and style.

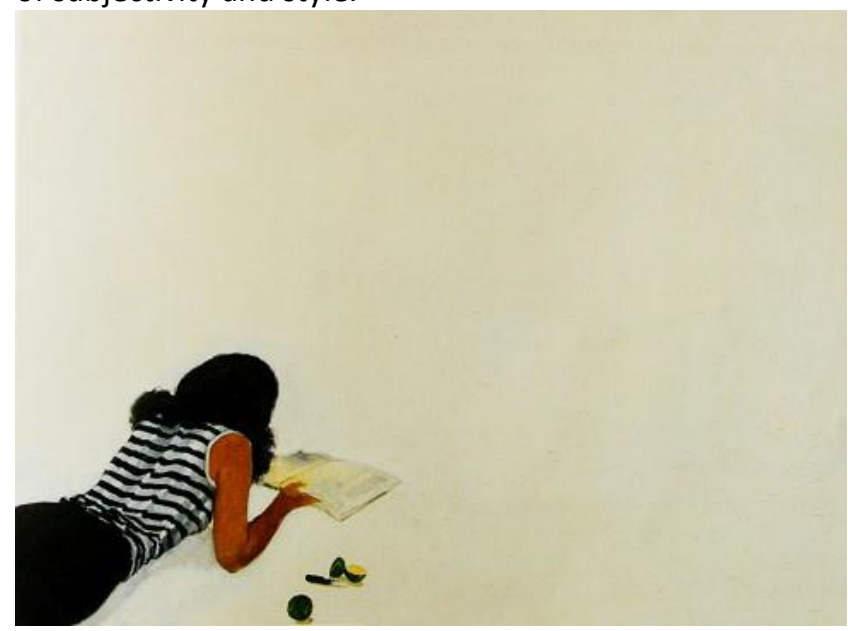

Source: https://wondersofpakistan.wordpress.com/2008/11/27/colindavid-avant-garde-of-non-conformist-painters/ (accessed on $5^{\text {th }}$ August, 2018)

Figure. 12. Colin David, Lady Reading, date unknown, oil on canvas.

Another important painter who embraces the image of females as a subject of his interest was lqbal Hussain (b. 1950). Being conscious about his surroundings as a part of the red-light area inside Lahore, he depicted realistic stories of women who lived in the same area. He portrayed the other side of his society and expressed how female has been used as a symbol of entertainment by the male dominated society. He focused on their gestures whether bodily or facial expressions to show their inner feelings. His work is a comment on his society as well. His strong sense of composition also adds to the strength of his subject. He mostly depicted the females nude and draped being in their typical environment. Most of his compositions seems to be inspired by the work of Degas (an Impressionist artist). Degas's strong sense of design, color palette and the attempt to play with foreshortened figures is reflective in the work of Iqbal Hussain. In (fig.13), a nude female is reclining on a sofa in a position that only her back is visible with her legs lifted higher making a cross. Her face is not visible however, it is covered with hairs. In the foreground, a still life has been focused with all the elements that represents the inside 
story associated with the subject depicted in this painting. A stool that holds a glass probably filled with wine, accompanying a packet of chips used as a snack and a basket filled with flowers i.e., roses and jasmine (a typical symbol used in the red-light area for amusement). Though, the subject is heart-touching and expressed a very sensitive side of a society but lqbal Hussain never felt afraid in depicting this harsh reality he was a part of. His conceptual approach with command on composition opened new vistas of experimentation for the younger generation as well.

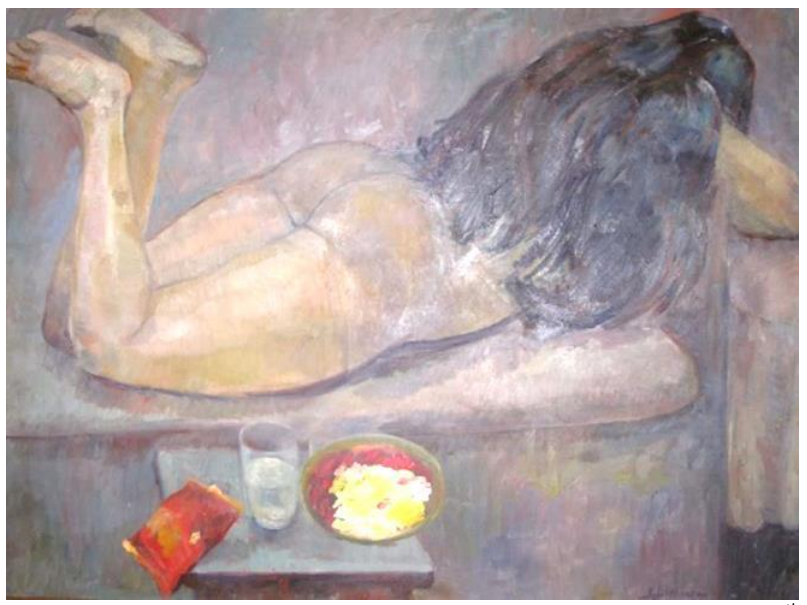

Source: http://globalwomenforum.net/Painting.aspx (accessed on $17^{\text {th }}$ July, 2018)

Figure.13. Iqbal Hussain, Untitled, 2012, oil on board, 91 $\mathrm{cm} \times 121.9 \mathrm{~cm}$.

Iqbal Hussain, emerged as an artist of red-light area during the period of Zia ul Haq's dictatorship, when he banned figurative art to spread the concept of Islamization in Pakistan only for getting political benefits. Iqbal Hussain was the one whose work was thrown out of Alhamra Art Gallery Lahore, because they were having the depiction of nude females. This restriction arose as a reaction against extremism; the artists who were practicing figurative art kept on doing their work but were not allowed to show it to the viewers publicly. That era became fruitful for the growth of calligraphic art and as a result a number of artists adopted that style of representation in their work. After Zia ul Haq's dictatorship, artists again got the freedom of expression and were allowed to display their work flavored with the liberal approach.

Besides Iqbal Hussain, Jamil Naqsh, Mansoor Aye, and Asad Faruki have used female figure as a source of inspiration in their work. Jamil Naqsh (b. 1938) has a specific style of portraying female figure and he normally associates it with a pigeon (fig.14). He was also inspired by cubism and the western approach of painting. He was mostly inclined towards Picasso in his approach towards making of art. The stylized rendering of his subject turned to be his signature mark as can be seen in his body of work. The strong contrast of light and dark also became a distinctive feature of his work. In this painting, the lady is shown holding two pigeons in both of her hands. Moreover, the cubistic approach is also evident that traces the influence of Picasso from the western world and of Shakir Ali from the native land. The layers of contrasting colors i.e., earthy brown and blue color are representative of the earth and the sky, worldly and celestial spaces.

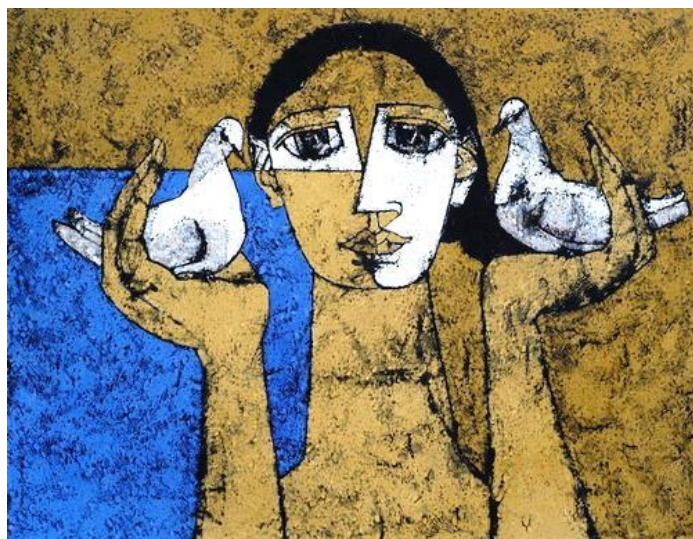

Source: http://www.aancollection.org/en/artist/work/art-space-jamilnaqsh (accessed on $19^{\text {th }}$ July, 2018)

Figure. 14. Jamil Naqsh, Woman and Pigeon, 2005, oil on canvas, $91 \mathrm{~cm} \times 121.9 \mathrm{~cm}$.

In this queue of Pakistani artists who used female imagery as a subject of their visual expression, Raja Changez Sultan (b. 1948) is also noticeable. He painted murky dreamy women in his paintings, for him perfection lies in that expression (fig.15). On the surface of paintings, mystery was left by the artist for the viewers. A Woman is depicted with a certain expression on her face with eyes being focused as the focal point that narrates a story of its own kind. The smooth layers of contrasting colors in a subdued fashion makes his work unique among others.

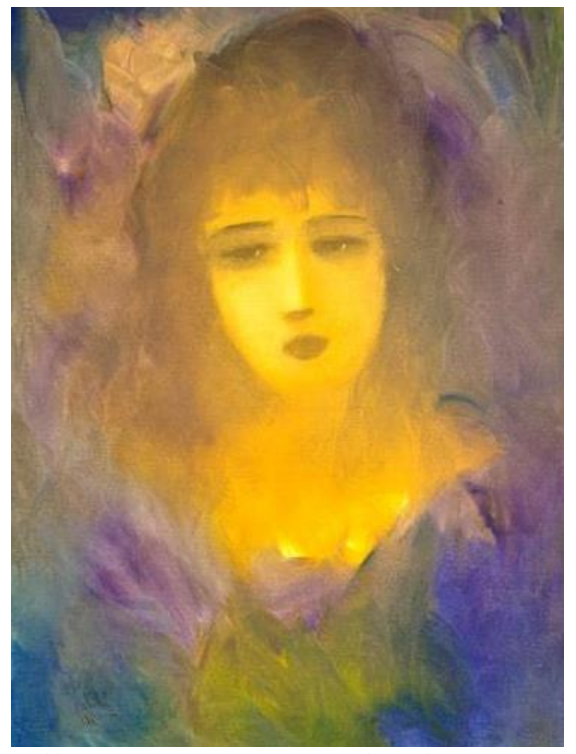

Source: https://www.youlinmagazine.com/blog/gallery-changez-whereart-meets-nature/Mjk= (accessed on $7^{\text {th }}$ August, 2018)

Figure. 15. Raja Chengez Sultan, Portrait of a Woman, date unknown, oil on canvas, artist's collection. 
Asad Faruki (b. 1946), a designer by professional experience is also known as a painter with greater understanding of design. He mostly works with mixed media on canvas and paper. Paper cuts, imagery of pop culture, screen printing technique and the interplay of text (mostly taken as cutouts), play important role on his designed surfaces. In (fig.16), over a rectangular surface which is used vertically, a circle occupies the position of a focal point. This part of the composition is a collage of mixed media where a female image taken from the pop culture is visible placed almost in the center of the composition. The model like image of the female is surrounded with the reference of English alphabets (text) of varied styles which has been used repetitively. This textual surface covers almost the half of the circular form from the upper register against the background of white color. Whereas, the lower half is colored red with the slight infusion of text at both the sides i.e., right and the left. Geometric patterns are more dominant in the overall composition. He mostly used to play with the design elements in the making of a composition and it is among the main features in his work. His inclination towards pop-imagery makes him distinguished among his fellow contemporaries. The posture of the female figure resembles a bit with the iconic image of 'Dancing Girl' from Indus Valley Civilization, though it represents the current fashion of the modeling world. The image of the female is enhanced with the decorative elements i.e., bangles, earrings and the treatment of her hairs. To show the delicacy of female figure the artist has used the image of a butterfly at her right corner, which adds beautification to the subject. Over the head of the female figure, a cutout resembling the shape of a ship is visible. This image also contains calligraphic text used in a repetitive manner. All the elements used in this composition enhanced the exquisiteness of the female image and also represents the current fashion in the world around.

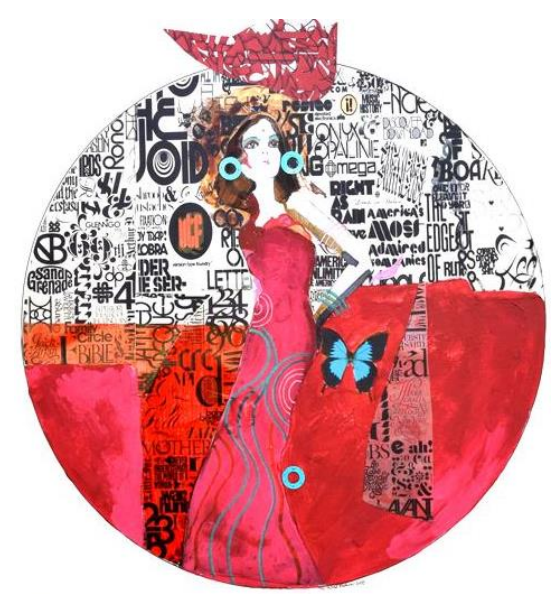

Source: http://www.artscenegallery.com/paintingdetail.asp? Artist=Asad\%20Faruki\&avail=1\&Page $=2$ (accessed on $9^{\text {th }}$ June, 2018)

Figure. 16. Asad Faruki, Untitled, 2010, mixed media on paper, $60.9 \mathrm{~cm} \times 76.2 \mathrm{~cm}$, artist's collection.
A wide circle of artists from the 1980's-90's including the prominent ones like Bashir Mirza, Ozzir Zubi, Najmi Sura, Hajira Mansoor, Bashir Ahmad, Khalid Saeed Butt, Munira Alam, Shazia Sikander and A.R Nagori etc. incorporated female imagery in their art. Besides these, among the list of artists who fused their personal experiences in art, Rubi Chishti stands out to be an artist of conceptually charged notion. She introduced a new way of looking at reality with thought-provoking visual vocabulary. From the selection of subject to its execution, she used her personal belongings to generate an expression that owned feelings. Her work mostly revolves around the representation of female. Her artwork depicts three dimensional handmade stuffed figures. In (fig.17), an installation based on six female figures sitting with the gesture of mourning is visible. Ruby had strong association with her mother who died because of cancer. She witnessed the pain of her mother during her illness before death and that feeling was present in the sensitively rendered body of work she produced. The intense yet extremely powerful visual imagery of her work connects with the viewer in a simple yet strong way. "She used old quilts from her family to construct a group of lamenting women". ${ }^{10}$ Ruby is known for her personalized imagery and intense expression. For her beauty lies in subjectivity rather than objective representation. Besides this she also introduced a new direction in art making while focusing on handmade three-dimensional figures.

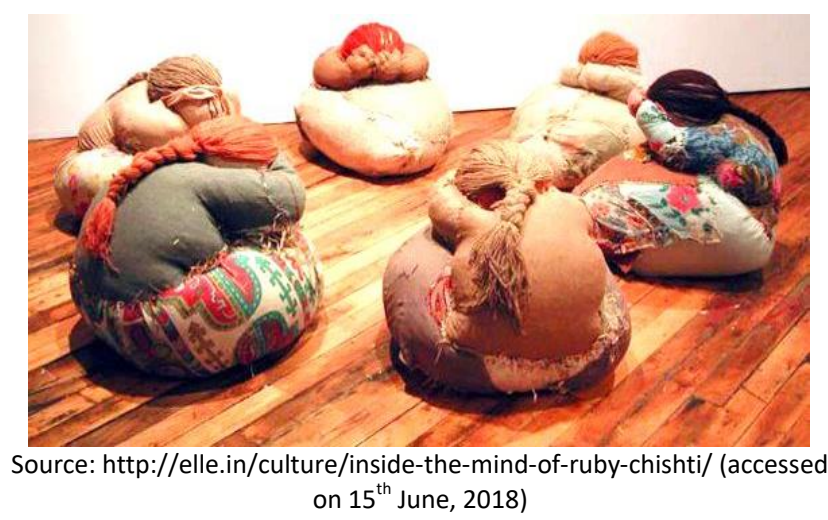

Figure. 17. Ruby Chishti, My birth will take a thousand times no matter how you celebrate it, 2000, cast fabric, stitched and stuffed with straw and yarn.

In the present age besides Rubi Chishti, Rahat Naveed Masud, R.M Naeem, Ali Azmat, Sumera Jawad, Waseem Ahmad, Saqiba Suleman and Imran Ali Kazmi are among those painters who are portraying female imagery in their own distinct style. Rahat Naveed Masud (b. 1953) has tried to infuse female with the spiritual element, most of her work is symbolic in interpretation. Her work portrayed mastery in skill and command on her medium. She mostly worked with pastel colors on hand made

${ }^{10}$. http://elle.in/culture/inside-the-mind-of-ruby-chishti/ (Accessed on $15^{\text {th }}$ June, 2018) 
paper, besides this she is a master of old paint as well. Her work is fused with mystic quality. Her incline towards mysticism provoked her to explore this aspect as a main subject of research in her PhD dissertation in the field of Studio Practice and as a result of that every element of visual representation in her work was flavored with spiritual dimension. She mostly portrayed her self portraits and in (fig.18), she has represented it with symbolic gesture. The focal point of the painting is the self portrait of the artist with a profile face (a prominent feature of miniature painting). She is holding a rose in her left hand that is adjacent to her chin. This specific posture of portrait making was inspired by the art of portraiture evident in miniature painting. A hallow is highlighted at the background of the female face to show the exposure of heavenly blessings on the artist, this aspect was very well represented by Christian art and was also highlighted in Mughal miniature paintings of the royal figures. The left corner of the painting depicts three pipal leaves whereas two are highlighted with streaks of chrome yellow color in order to create the effect of gold (a symbol of religious prosperity). These leaves are also associated with divine essence. The background of the painting represents an open sky with the overtones of heavenly state, clouds and stars are pre-dominant feature of this mystical sky. In the foreground, that gives the impression of an open window, represents this temporal world. An unlocked lock has been depicted aside with keys. This lock discloses that the artist has unlocked all the worldly barriers for unification with the divine One and has shown herself as the representative of God on this world.

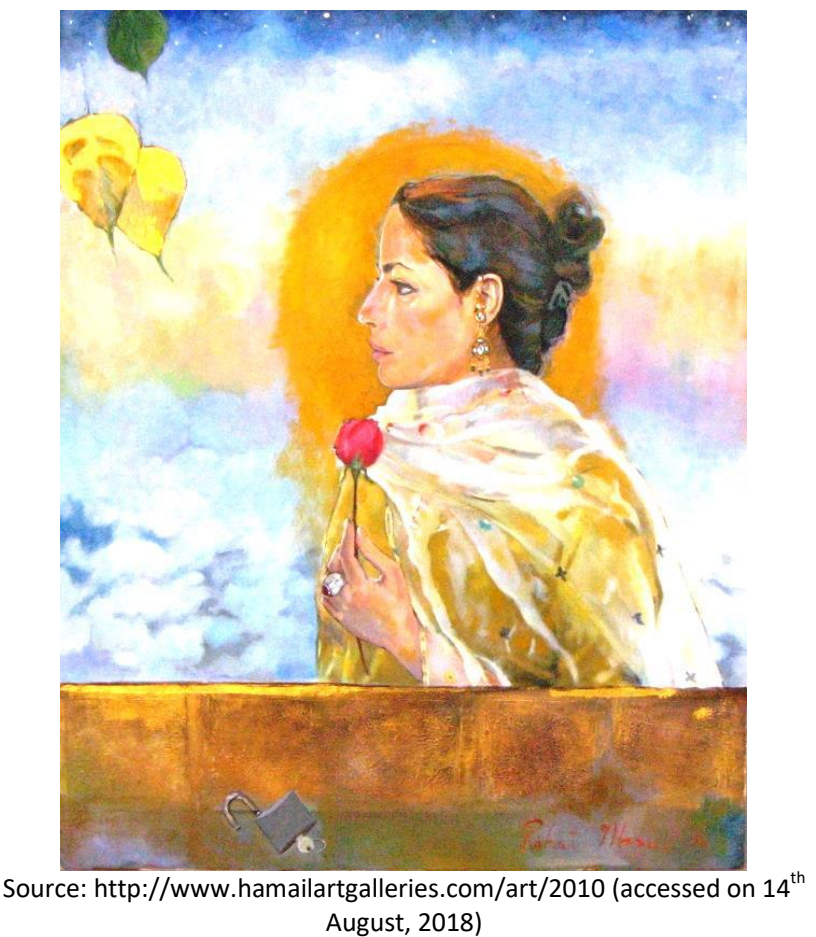

Figure. 18. Rahat Naveed Masud, Self-portrait, 2010, oil on canvas, $88.9 \mathrm{~cm} \times 109.2 \mathrm{~cm}$, artist's collection.
Ali Azmat (b. 1973), another promising artist of the contemporary age has explored female image as a subject of representation in his work. His conceptual understanding and command on technique also adds to the quality of his work. Most of his work embrace single figure compositions. He emerged on the art scene of Pakistan as a figurative artist with emphases on the incorporation of female figure in his compositions. Though, every of his work contains the element of silence that speaks for itself. Every element he used had a strong metaphorical nuance. In (fig. 19), a complete profile image of the female is visible. She is sitting with crossedlegs over a bed or a platform which is covered with a drapery of maroon color. The background of this painting is of red color (a color which is very difficult to balance in a composition). The maroon color of the drapery compliments the color of the background. The striking feature of the composition is the addition of contrasting/complementary colors, a challenging aspect balanced by the artist with his painterly skill. The focal point of the painting is the seated figure with probably closed eyes which seems as if she is lost in some thought. She is wearing traditional dress of Pakistani culture i.e., shalwar kameez of blue color whereas her skin color reflects the shades of red as seen in the background. She is holding a green colored bowl possibly it contains apples as two apples are visible next to the bowl. Apples are mostly associated with female as being the reason for the expulsion of Adam and Eve from the paradise. In the foreground a plant with a curvilinear rhythm overlaps the over all activity of the middle ground where the focal point lays. The plant with elongated green leaves at its top serves as an umbrella that shelters the female figure. The green color of the leaves balanced the green color of the bowl. Ali Azmat besides his other contemporaries is known for his command on compositional balance, conceptual context and grasp on painterly quality. The calm posture of his figures heightened their elegance that speaks for themselves.

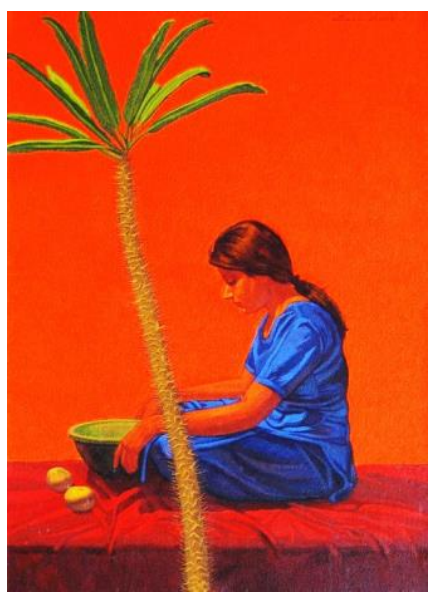

Source: http://cliftonartgallery.com/artist/ali-azmat/ (accessed on $15^{\text {th }}$ August, 2018)

Figure. 19. Ali Azmat, Untitled, 2008, oil on canvas, 50.8 $\mathrm{cm} \times 76.2 \mathrm{~cm}$, private collection. 
Saqiba Suleman (b. 1984), a follower of Ali Azmat was also his student. Saqiba is known for her females surrounded with patterns of floral imagery. Her openended compositions with emphases on female figure as an integral part of God's scheme of creation highlights the elegance of their personality as well. The metaphorical representation of flowers as a main feature of her paintings also focused on females as a source of beautification in this universe (fig. 20). Flowers symbolizes female as a unit of elegance, delicacy and perfection. Her work contains sensuous quality as well. The interplay of three-dimensional figures over twodimensional surface also heightened the perfection of her painted figures. Her compositional sense and control over subject make her work astonishing. It is appropriate to quote the poetic lines by Allama Muhammad Iqbal (a poet of the east from twentieth century) while looking at her work, which narrates:

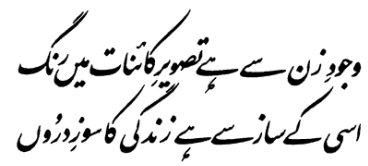

Translation:

"The picture that this world presents from woman gets its tints and scents:

She is the lyre that can impart pathos and warmth to human heart". 11

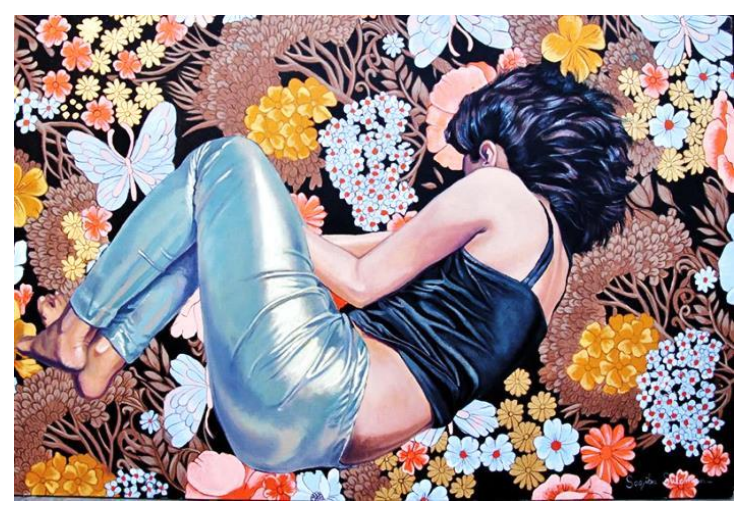

Source: http://www.vervemagazine.in/arts-and-culture/paintingbeyond-the-lines-saqiba-suleman (accessed on $28^{\text {th }}$ August, 2018)

Figure. 20. Saqiba Suleman, Dreamer, 2018, oil and acrylics on canvas, size unknown, private collection.

Sumera Jawad (b. 1967), known as a painter of female image and imagery, exclusively explored and portrayed her understanding of this iconic symbol of representation. She also incorporated some historical images, used in multiple civilizations and religions in her work but expressed her own thoughtful reflections. In (fig. 21), a portrait titled self is depicted by the artist where she has fused her self-image with the image of Goddess. She feels every woman owns a goddess in herself because of all the attributes she is associated with. She also believes that women are fortunate enough to be special as they can experience all the feelings which sometimes men cannot

\footnotetext{
${ }^{11}$. http://iqbalurdu.blogspot.com/2011/04/zarb-e-kaleem-103aurat.html (accessed on 1st November, 2018)
}

experience and they remain concealed for them. A female is the perfect example of God's creative scheme and this aspect of her creation makes her superior among the other creations of God.

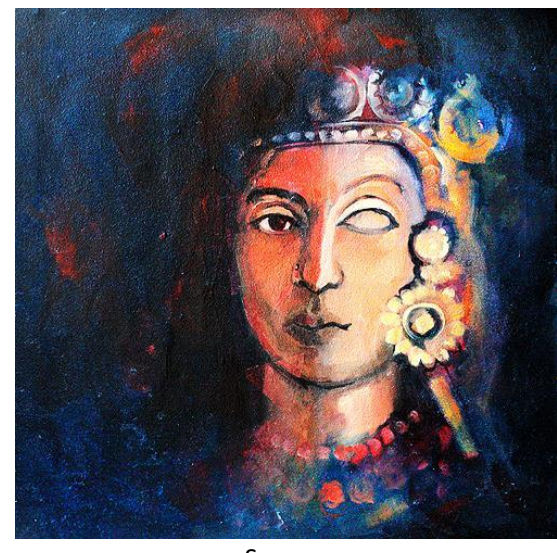

Source:

https://www.thefridaytimes.com/beta3/tft/article.php?issue=20110722 \&page $=20$ (accessed on $25^{\text {th }}$ July, 2018)

Figure. 21. Sumera Jawad, Self, 2011, mixed media on canvas

\section{Conclusion}

After analyzing female imagery executed by diversified artists, it could be concluded that this symbol has been practiced by almost all regions and has a unique impact in the development of art and is still playing an integral role in recording the diverse cultures with emphases on multiple philosophies related with female imagery. This subject of interpretation and expression also widened multiple directions for the artists. More than sixty percent Pakistani artists are involved in the same business but are trying to use the female icon with diverse means of representation. Looking at the profound depiction of female imagery in Pakistani art, it is appropriate to conclude that she has been used as an icon of exquisiteness, moreover a unit of perfection and will remain so.

\section{References}

[1]. Ahmed, Jalaluddin. 1970. Art in Pakistan. Pakistan Publication, Karachi.

[2]. Ali, S. Amjad. 2000. Painters of Pakistan. National Book Foundation, Islamabad.

[3]. Butt, Khalid Saeed. (Ed.). 1988. Paintings from Pakistan. Idara Saqafat-e-Pakistan, Islamabad.

[4]. Craven, Roy C. 1976. Indian Art: A Concise History. Thames and Hudson, London.

[5]. Hasan, ljaz-ul. 1991. Paintings in Pakistan. Ferozesons, Lahore.

[6]. Hashmi, Salima. Quddus Mirza. 1997. 50 Years of Visual Art in Pakistan. Sang-e-Meel Publications, Lahore.

[7]. Kleiner, Fred S. Christin J. Mamiya. 2005. Gardener's Art through the Ages. 12th Ed. Thomson Wordsworth, New York.

[8]. Naqvi, Akbar. 1998. Image and Identity: Fifty Years of Painting and Sculpture in Pakistan. Oxford University Press, Karachi.

[9]. Sirhandi, Marcella Nesom. 1992. Contemporary Painting in Pakistan. Ferozesons Pvt Ltd, Lahore.

[10]. Wheeler, Mortimer. 1970. Civilization of the Indus Valley and beyond. Thames and Hudson, London. 